\title{
Development of Interactive Learning Multimedia Reading Early Children's Beginning
}

\author{
Ostawati Gultom ${ }^{1}$, Anita Yus $^{2}$, Sriadhi $^{3}$ \\ ${ }^{1}$ Postgraduate Program in Universitas Negeri Medan, Indonesia \\ ${ }^{2,3}$ Universitas Negeri Medan, Indonesia \\ gultom5osta@gmail.com
}

\begin{abstract}
Development of Interactive Learning Multimedia Learning Beginning for early childhood (5-6 years) in Christian Kindergarten 3 District Medan Kota, Medan City. Postgraduate Basic Education Study Program, State University of Medan. The purpose of this research and development was to determine the feasibility and effectiveness of interactive learning multimedia for early childhood reading in Group B TK Nasrani 3, Medan Kota District, and Medan City. The development model in this study refers to the $4 D($ Four-D) researches and development model which consists of 4 main stages, namely define, design, develop, and disseminate. The subjects in this study were 3 expert validators and 20 students of Group B TK Nasrani 3 Medan. The product of this research is a multimedia interactive learning software product on the material of celestial objects for group B students TK Nasrani 3 Medan. The results showed that (1) the feasibility level of interactive multimedia learning pre-reading based on: a) the validation results of the material experts on the feasibility of content by instructional media experts by 3.6, learning material experts by 3.7, while design experts 3.5 in the category with "very worthy ". b) The practical results of the teacher state that children get very good responses and responses. This can happen because the steps loaded in multimedia learning have instructions and are easily understood by children. 2) the results of the effectiveness of interactive learning multimedia that were developed showed the average result of reading the beginning of the child on the results of initial observations was $45 \%$, which means the child began to develop and the result of the final observation was $83 \%$, which means that the child developed very well.
\end{abstract}

Keywords interactive learning multimedia; beginning reading; early childhood

\section{Introduction}

Childhood Education is a coaching effort aimed at children from birth to 6 years of age which is carried out through educational stimuli to assist physical and spiritual growth and development so that children have readiness to learn to enter further education. Kindergarten is in the form of a formal pathway organized by early childhood education program unit education at the age of 4-6 years, Group a children aged 4-5 years and Group B children aged 5-6 years. Early childhood education (PAUD) is a form of education that focuses on laying the foundation for physical growth and development (Kurniawan, 2020).

Kindergarten education is one of the most formal education fundamentals to prepare for further education. Therefore at this time it is necessary to make educational efforts including efforts to stimulate, guide, nurture, assist and provide learning activities that can 
develop children's potential so that children can develop optimally. Because when the child experiences a period of optimal growth and development, it will affect the development of life in the future. This means how important it is for children to be given the correct mental stimulation while studying in Kindergarten to give satisfactory results. Early childhood education is a basic and strategic for human beings (Handayani, 2020). In line with the development of the education world in Indonesia, the competition level of education is very strict and need to be improvement especially in early childhood education (Simatupang, 2019).

The level of achievement standards for child development as stated by the Minister of National Education Regulation Number 146 of 2014 in the scope of language development for children aged 5-6 years, in the scope of literacy development includes; mentioning symbols of vosymbolskaland known consonants, recognizing the sounds of the initial letters of the names of objects around them, mentioning groups of pictures that have the same initial sound/letters, and reading their own names. Bond (1975) argues that reading beginning early childhood is an introduction to symbols of written language which is a stimulus that helps the process of remembering what is read, to build an understanding through the experiences they have had. (Nanda 2012:3).

Reading the beginning is one aspect of language development that is owned and developed in early childhood. Beginning reading is a very unique skill and plays an important role in the development of knowledge, and as a means of communication for human life. The ability to read is very important for children. Children's abilities can more easily learn and master other fields of science. Weak reading skills certainly have a negative impact, both mentally and in terms of academic achievement. The weakness of children in reading can make them discouraged from having no self-confidence, and cause low learning motivation. This is supported by the results of Pertiwi's research (2016: 760) which states that reading the beginning has a great effect on children's readiness to enter the next stage or level.

From the results of observations at TK Nasrani 3 Medan, Medan Kota District, on November 182019 towards group B aged 5-6 years in the odd semester, it was found that most of the children of group B were able to recognize letters (18 children out of 20 children), but still have difficulty reading words (5 out of 20 children). Thus, the early reading ability of group $\mathrm{B}$ children was still low. This can be seen by the teacher prioritizing the achievement of learning activities to meet a fairly dense educational curriculum so that it can be completed on time.

The rapid development of technological advances in education makes it easy for teachers to package and present learning so that it can increase stimulation and motivation for the teaching and learning process. The goal is that students can be motivated to learn more enthusiastically and creatively. The thing that needs to be considered by the teacher is the use of multimedia that is appropriate and appropriate for any given subject matter, because the use of appropriate media can support success in achieving efficient and effective learning goals so that it is expected that student learning development will increase.

Based on the flow of thoughts that have been described above, it can be questioned whether the development of interactive learning multimedia for early reading can improve early reading skills of early childhood by conducting research with the title "Development of Interactive Reading Multimedia Learning in Early Childhood" while the purpose of this study is to know the feasibility and effectiveness of the use of multimedia interactive learning in reading the beginning of the Early Childhood. 


\section{Research Methods}

Research Interactive learning using multimedia products $\mathrm{R} \& \mathrm{D}$ research and development (Research andDevelopment). This study aims for the purpose of this study, namely to determine the feasibility and effectiveness of using interactive learning multimedia in reading the beginnings of Early Childhood Development. Model in this study as proposed by Thiagarajan. The model consists of four stages of development, namely: pendefinisian (define), design, development (develop), and penyebaran.

\section{Discussion}

\subsection{Testing}

Product trials are carried out to obtain data used to determine product weaknesses that develop the basis for revising multimedia products. The initial stage of the trial was, the initial reading multimedia product was tested by three media experts, namely material experts, media experts and design experts. Furthermore, the trial results of the experts are analyzed and used as input for product improvement. After the product revision is complete, the product is tested on children, this is to determine children's responses or impressions of multimedia reading at the beginning, trials in children include individual trials, small group trials and large group trials. The results of the trials on these children were then analyzed and used as input for improving the final product.

\subsection{Trial}

\section{a. The trial Subjects in Research}

This development was early childhood at TK Nasrani 3 Medan, totaling 20 children. Techniques and instruments for data collection Techniques used to collect data during the process of developing multimedia products for learning to read this introduction are using interview techniques, questionnaires, and observations. The instrument used to collect data is in the form of an assessment instrument to assess products that have been developed from material aspects, media aspects and design aspects. Instruments are given to material experts, media experts and design experts. While the instrument for children is used to determine children's responses about multimedia being developed.

Interviews were conducted to collect data from children and teachers in connection with the needs analysis required for the development of multimedia learning products, while questionnaires were used to determine the effectiveness or feasibility of product design as a multimedia learning program from material experts, media experts and design experts. This questionnaire is used for quantitative data collection. Instruments are given to material experts to obtain the feasibility of the developed program in terms of the accuracy of the material, aspects of material content, aspects of material evaluation, aspects of language, aspects of clarity of information and aspects of motivation. The results of the research are used as the basis for implementing revision of multimedia learning products The instrument is then given to the media expert to obtain data about the feasibility of the program developed in terms of suitability, convenience, attractiveness and benefits. The results of the study serve as the basis for implementing revision of multimedia learning products. The next instrument is given to the design expert to get data about the feasibility of the program being developed. The results of the assessment are used as material for revising and improving the product. The evaluation sheet uses an interval scale of 5 with the type of question appropriate to the position as an assessor. The next questionnaire instrument was given to the child to obtain data about the child's response to the resulting 
program from the child's point of view when testing the product. The questionnaire for children uses the Guttman scale, a measurement scale with this type will get a firm answer, namely "like it-not"; "True False"; "Easy-difficult"; "Positive-negative". The answers from the children made the highest score "one" and the lowest score "zero".

\subsection{Validity of the Instrument}

The validity of the instrument in the study in the form of making a questionnaire / questionnaire grid for material experts, media experts and design experts as well as children / users, was given to a learning expert lecturer who appointed as validator to validate the instrument, then the results of the validation are analyzed and corrected if there are errors in the preparation of the instrument. After the instrument is declared valid by the validator, then the instrument can be used to conduct research.

\subsection{Data Analysis Technique}

The data analysis technique for the feasibility of learning multimedia products uses the Mardapi scale which is obtained then converted into a value with a scale of 4 , namely dividing the standard value into four scales or four qualifications. Scale 4 in this research and development statistical technique is very good (4), good (3), not good (2), very not good (1). If the media expert, material expert and design expert give a "very good" response to a question item, then the question item score is "4" and so on.

While the questionnaire data analysis technique for children used the Guttman scale and the percentage of children's answers. The percentage for each possible answer is obtained from dividing the frequency by the number of test subjects.

Table 1. Conversion of Achievement Levels

\begin{tabular}{|c|c|l|}
\hline No & $\begin{array}{c}\text { Interval } \\
\text { Score }\end{array}$ & \multicolumn{1}{|c|}{ Eligibility Criteria } \\
\hline 1. & $0.75-1.00$ & Very Eligible \\
\hline 2. & $0.50-0.74$ & $\begin{array}{l}\text { Eligible without } \\
\text { revision }\end{array}$ \\
\hline 3. & $0.25-0.49$ & $\begin{array}{l}\text { Not feasible needs } \\
\text { revision }\end{array}$ \\
\hline 4. & $0.00-0.24$ & $\begin{array}{l}\text { Not feasible needs } \\
\text { revision }\end{array}$ \\
\hline
\end{tabular}

From these calculations, interactive multimedia learning to read the beginning can be said to be "feasible" to use in learning if the feasibility reaches> 0.50 on the contrary, It is said "Not feasible" if the percentage of feasibility is $\leq 0.50$.pre-

Data analysis techniques for the effectiveness of interactive learning multimedia products for reading the beginnings using the formula used in calculating the percentage of scores for reading activities are as follows: 


$$
\mathrm{PS}=\frac{\mathrm{F} \times 100 \%}{\mathrm{~N}}
$$

Keterangan:

$$
\begin{aligned}
& \text { PS }=\text { Percentage Score } \\
& f=\text { Total Score obtained } \\
& \mathrm{N}=\text { Total maximum score of }
\end{aligned}
$$

\subsection{Research Development of Multimedia Products Learning by Approach}

This communicative is developed through the research planning stage. Planning research conducted dalam literature, data obtained from information gathering activities are as follows.

First, the standard level of achievement of child development within the scope literacy development includes; mention simbol-letter symbol vowel and consonants known, familiar sound of the initial letter of the name of the objects around it, mentioning groups of images that have sound /hurlyf same beginning, and read his own name. Data obtained from the Minister of National Education Regulation Number 146 of 2014 concerning the standard level of achievement of early childhood development.

Second, the use of multimedia learning has a very good impact on the learning process and outcomes, multimedia is very helpful for students in understanding the concept of material in a concrete manner so that it is not abstract. Third, the use of komputer very helpful in learning.

At the field study stage, the data obtained were based on observations and interviews with the head of kindergarten and group B children, namely (1) learning media (Sugiyono, 2011: 141) used learning was simple media in schools, such as blackboards, children's worksheets. , black and white lettering card; (2) the teacher becomes the center of learning and the child just sits in their chair so that the child does not play an active role in the learning process; (3) the results of the child's learning varies, there have reached the standard level of development, but also banyak yet; (4) many children have difficulty understanding the concept of vocal and consonants, this happens because children find it difficult to distinguish the concepts of each letter form; (5) the school already has facilities such as LCD projectors, laptops and active speakers. However, their utilization is still lacking, such as LCD projectors, usually used for watching cards or children's dance music videos; (6) teachers are used to operating laptops in their daily activities; (7) of the 28 children interviewed, 19 had laptops at home and used to use them to play games and watch, while the other 9 children did not have laptops, but had used them to play games and watch.

The results of the data obtained from library research and field studies are then used as material for consideration and input to design and develop interactive learning multimedia products for pre-reading. Learning multimedia produced in the research was developed by using Adobe Flash CS3 Software. Multimedia resulting from this development generally consists of: (a) an opening page containing multimedia titles, namely: interactive learning to read early childhood with material on recognizing celestial objects; (b) The main menu consists of the material menu which includes a menu of recognizing letters and alphabets, reading beginnings and learning videos. (c) the hint menu contains reference symbols using media. (d) indicator menu contains indikator who dikembang; (e) games; guess the picture, complete the initial letter, and complete words into simple sentences. This game serves as entertainment for children and also as a repetition of the material learned by children which is presented in the form of a game fun; (f) the development profile contains the identity of the multimedia developer. 
Validation Results Material Experts Validation is carried out by providing the developed product to the validator to assess each aspect and provide an assessment by filling out the 4 scale questionnaire that has been provided. In the validation process, researchers obtained quantitative data and qualitatively very supportive to development and refinement product multimedia learning developed.

Material expert validation was carried out to determine the quality of interactive learning multimedia products in terms of material aspects. The aspects assessed include learning aspects with 3 items of material accuracy assessment, 7 items of material content, 3 items of material evaluation, 3 items of language, 2 items of clarity of information, 2 points of motivation. The results of the material expert's assessment can be seen in table 2 .

Table 2. The Results of the Expert's Assessment of the Material

\begin{tabular}{|c|c|c|}
\hline $\begin{array}{c}\text { Aspects of the } \\
\text { Assessment }\end{array}$ & $\begin{array}{c}\text { The Number } \\
\text { of } \\
\text { Questions }\end{array}$ & Average \\
\hline $\begin{array}{c}\text { Provisions } \\
\text { Material }\end{array}$ & 11 & 3.7 \\
\hline $\begin{array}{c}\text { Content of the } \\
\text { Material }\end{array}$ & 26 & 3.7 \\
\hline $\begin{array}{c}\text { Material } \\
\text { Evaluation }\end{array}$ & 11 & 3.7 \\
\hline Language & 11 & 3.7 \\
\hline $\begin{array}{c}\text { Clarity of } \\
\text { Information }\end{array}$ & 8 & 3.5 \\
\hline Motivation & 7 & 3.72 \\
\hline Average & Very Eligible \\
\hline Category & \\
\hline \multicolumn{2}{|c|}{} & 4 \\
\hline
\end{tabular}

\subsection{Results of Expert Media}

Validation Validation is carried out to determine the quality of interactive learning multimedia in terms of the media aspect. The aspects assessed include 7 points of conformity, 6 points of convenience, 6 points of attractiveness and 2 points of usefulness. Assessment using a scale questionnaire 4. The results of the media expert's assessment can be seen in table 3 .

Table 3. Recap of the Average Score of the Media Expert Validation Results

\begin{tabular}{|c|c|c|}
\hline $\begin{array}{c}\text { Aspects of } \\
\text { Assessment }\end{array}$ & $\begin{array}{c}\text { Number } \\
\text { Grain } \\
\text { Problem }\end{array}$ & Average \\
\hline Conformity & 7 & 3.6 \\
\hline
\end{tabular}




\begin{tabular}{|c|c|c|}
\hline Ease & 6 & 3.5 \\
\hline $\begin{array}{c}\text { attractiveness } \\
\text { of the }\end{array}$ & 6 & 3.7 \\
\hline Expediency & 2 & 4 \\
\hline \multicolumn{2}{|c|}{ Average } & $\mathbf{3 . 6}$ \\
\hline \multicolumn{2}{|c|}{ Category } & $\begin{array}{c}\text { Very } \\
\text { Decent }\end{array}$ \\
\hline
\end{tabular}

\subsection{The Result of Expert Design Validation}

Validation is performed to determine multimedia quality interactive learning from the aspect of Design . The aspects assessed include 8 points of general appearance, 5 points of special appearance and 7 points of Media Presentation. Assessment using a scale questionnaire 4 . The results of the media design expert's assessment can be seen in Table 4

Table. 4 Recap Average Score Results Validation Expert Design

\begin{tabular}{|c|c|c|}
\hline $\begin{array}{c}\text { Aspects } \\
\text { Assessed }\end{array}$ & Score & Average \\
\hline Display Works & 8 & 3.6 \\
\hline View Custom & 5 & 3.6 \\
\hline $\begin{array}{c}\text { Presentation of } \\
\text { Media }\end{array}$ & 7 & 3.7 \\
\hline \multicolumn{2}{|c|}{ Average } & 3.6 \\
\hline \multicolumn{2}{|c|}{ Category } & Very Decent \\
\hline
\end{tabular}

\subsection{Results from Pilot}

Trials to individual, small group and group Field work was conducted to obtain evidence empirical impropriety learning multimedia interactive reading developed beginning in identifying mistakes and getting suggestions to revise the product. The data obtained from the results of children's responses to interactive learning multimedia products developed for reading the beginnings are then converted into the Guttman scale. Testing is done by showing the product and briefly explaining the application use multimedia interactive learning reading introduction to children then the child gives a response about the quality of the product in terms of ease, attractiveness, and clarity of narrative or guidance. Average results of responses of children in the individual trial were 0.96 with the "very feasible" category, the small group trial was 0.98 with the "very feasible" category, and the group trial pitch was 0.93 in the "very feasible" category. Based on individual trials, small groups and field groups on interactive multimedia learning to read the beginning can be recapitulated as follows: 
Table 5. Recapitulation ofTrial Results

\begin{tabular}{|l|l|c|c|}
\hline No & \multicolumn{1}{|c|}{$\begin{array}{c}\text { Trial } \\
\text { Group }\end{array}$} & $\begin{array}{c}\text { Score } \\
\text { Average }\end{array}$ & Category \\
\hline 1. & Individual & 0.96 & Very Eligible \\
\hline 2. & Small Group & 0.98 & Very Feasible \\
\hline 3. & Field Group & 0.93 & Very Eligible \\
\hline \multicolumn{2}{|c|}{$\begin{array}{c}\text { Cumulative } \\
\text { Average Score }\end{array}$} & 0.96 & Very Feasible \\
\hline
\end{tabular}

Based on table 5, it can be seen that the cumulative average of individual, small group, and field group trial results for interactive multimedia learning on early reading for early childhood is 0.96 and this average score is in the "very feasible" category. The final form of this developed learning multimedia product is software that is packaged in the form of an interactive learning CD. The learning platform generated in the research was developed using Adobe Flash Software CS3.

This product contains a main menu consisting of a material menu which includes a menu for recognizing letters and alphabets, a menu for starting reading and a learning video menu, a menu of instructions, an indicator menu, a profile menu and a games menu. This multimedia program is aimed at early childhood group B aged 5-6 years.

Multimedia product development process follows the stages in development and has also been validated by three expert validators, namely one material expert, one media expert and one design expert, the trial consists of three stages, namely individual trials, small group trials and field trials with a total of 28 early childhood.

Based on the results of the assessment carried out by material experts on product quality in terms of the aspects of material provision, material content, material evaluation, language, clarity of information and motivation, the average score was 3.7 with the category "very feasible". Meanwhile, the results of the assessment carried out by media experts on the quality of multimedia learning developed in terms of suitability, convenience, attractiveness and usefulness received an average score of 3.6 in the "very feasible" category. As well as the results of the assessment carried out by design experts on the quality of learning multimedia developed in terms of general appearance, special aspects and media presentation got an average of 3.6 with the category "very feasible".

Description of the data in the results of this study were observations to determine the ability to read the beginning before and after using multimedia learning. Where the purpose of holding both these observations to get a pet comparison of both the learning process. The implementation of the observation assessment of 20 children was carried out to group B children TK Nasrani 3, Medan Kota District. Before being given the learning media reading skills of children are at the beginning of the average-average $51 \%$. Wherein theindiksaid letterator vokal and consonants there are $71 \%$ of children at a score of 4 by 2 children, 3 score as many as 13 children and a score of 2 are as many as five children so that they can be categorized and developed according to expectations. In indikator recognize letters vokal and consonants there are $48 \%$ of children at a score of 4 nobody, a child, a score of 3 by 3 children, a score of 2 by 12 and a score of 1 by 5 children, so categorized began to develop on indikator complete the letter initializing the word there are $47 \%$. Where children on a score of 4 are 1 child, a score of 3 is 3 children, a score of 2 
is 9 and a score of 1 is 7 children, categorized as starting to develop. In indikator connected the word in the picture, there are 33\%. Where the child on a score of 4 was not a child, a score of 3 was no child, a score of 2 was 6 and a score of 1 was 14 children, categorized as starting to develop, then in arranging letters into words there were $28 \%$. Inmana child on the score of 4 is not a child, not a child's third score, a score of 2 by 3 and a score of 1 as many as 17 children, categorized as undeveloped. Then converted to the assessment, namely:

Table 6. Assessment Standards Observation Meanwhile, before and after Using Multimedia Interactive Learning

\begin{tabular}{|c|c|}
\hline Achievement & Description \\
\hline $80-100 \%$ & $\begin{array}{r}\text { Developing Very Good } \\
\text { (BSB) }\end{array}$ \\
\hline $60-79 \%$ & $\begin{array}{c}\text { Developing Appropriate } \\
\text { Expectations (BSH) }\end{array}$ \\
\hline $30-59 \%$ & $\begin{array}{c}\text { Start Evolving } \\
\text { (MB) }\end{array}$ \\
\hline $10-29 \%$ & Not Evolve (BB) \\
\hline
\end{tabular}

By Tables 5 and 6 above show the child's beginning reading ability before using learning media. Before being given learning media, the child's initial reading ability was at an average of $51 \%$. which means the results of children's initial observations in pre-reading ability are in the criteria of starting to develop (MB).

As for the results of observations after using interactive learning multimedia using adobe flash. Meanwhile, to determine the level of early reading skills of children after using the developed learning media, namely interactive learning multimedia using adobe flash.

The implementation of the observation assessment of 20 children was carried out to group B children TK Nasrani 3, Medan Kota District. After being given the learning media, the child's initial reading ability was at an average of $83 \%$. Where the indicators mention vowels and consonants there are $96 \%$, children with a score of 4 are 17 children, a score of 3 is 3 , while a score of 2 and a score of 1 is not a single child so it can be categorized as very well developed. In indicator recognize vowels and consonants are $76 \%$ of children at a score of 4 by 4 children, scores 3 as many as 14 children, a score of 2 by 2 children and a score of 1 was one child, and categorizing them develop according to expectations on indikator complete the initial letters of the words there are $84 \%$. Inmana child on a score of 4 by 8 children, 3 score as many as 14 children, a score of 2 in 1 child and nobody scores 1 child, growing very well categorized. In indikator connected the words on the picture are $80 \%$. Inmana child on a score of 4 as many as 7 children, 3 score of 10, a score of 2 for 3 children and a score not one child, are considered developed very well, Then arrange the letters into words there are $80 \%$. Where children on a score of 4 were 8 children, a score of 3 was 8 children, a score of 2 was 4 and a score of 1 was not a single child, categorized as very well developed.

Based on the data from the initial and final observations that have been carried out by the teacher, it can be seen that the child's beginning reading ability increases before the 
use of Interactive Learning Multimedia using Adobe Flash Before using Interactive Learning Multimedia, the child's beginning reading ability is at an average of $45 \%$ of children can be categorized as Starting thrive (MB). Furthermore, after using Interactive Learning Multimedia, the final score of observations for children's early reading ability was obtained $83 \%$. This assessment is in the very well developed criteria (BSB). Wherein theindiksaid letterator vokal and consonants an increase of $25 \%$ from $71 \%$ to $96 \%$ with the criteria developed very well. In indikator recognize letters and consonants an increase of $28 \%$ from $48 \%$ to $76 \%$ with the criteria developed very well. In the indicator completing the initial letters of the word, there was an increase of $37 \%$ from $47 \%$ to $84 \%$ with very well developed criteria. In indikator connecting word pictured an increase of $47 \%$ from $33 \%$ to $80 \%$ with the criteria developed very well and the indikator arrange letters into words also increased by $52 \%$ from 28 to $80 \%$ by criteria developed very well.

This shows that there has been an increase in children's beginning reading skills with the theme of the universe, the sub-theme of celestial bodies from the initial observation and the final observation by $37 \%$.

The characteristics of the pre-reading learning multimedia program and the results of this development have several advantages. These advantages include (1) the presentation is a combination of several media, namely; text, images, sound, animation, interactive which helps children to actively build their own knowledge, (2) this multimedia file is in the form of an application (* .exe), so it can be operated immediately without installing any software, (3) can provide feedback in it, (4) helping teachers to apply in the learning process.

During the research process, the response data, suggestions and comments from the accompanying teacher regarding multimedia learning to begin reading have advantages between alin, pictures and learning videos that are very interesting, making it easier for children to remember the material and not afraid to try multimedia programs, the display of the material is able to sort the flow children think, children look very enthusiastic about learning, games are very good and according to children's development.

\section{Conclusion}

Based on the formulation, objectives, results and discussion of research on the development of interactive multimedia learning using adobe flash to improve pre-reading skills in children 5-6 years at TK Nasrani 3 Medan, it can be concluded as follows: (1) The feasibility level of multimedia interactive learning on pre-reading : a) The results of validation from material experts on the feasibility of the content of the developed learning multimedia are included in the "Very Good" category. Based on learning design experts on the presentation of interactive learning multimedia using adobe flash development, it is included in the "Very Appropriate" category. b) The practical results from the teacher state that all teachers need interactive multimedia learning using adobe flash in the learning process while children are more happy to learn and it is easier for children to read the beginning by using interactive learning multimedia. (2) The results of the effectiveness of the developed learning multimedia show that the ability to read the beginning of the child after using interactive learning multimedia is higher compared to not using interactive learning multimedia, where the average value of the child's initial observation results is $45 \%$ and the result of the final observation increases to $83 \%$. Thus it can be concluded that learning using interactive learning multimedia using adobe flash is more effective and can improve pre-reading skills in group B children at TK Nasrani 3 Medan. 


\section{References}

Anita Yus. (2015). Early Childhood Education Model. Jakarta: Prenada media Group Kemendikbud. (2014). Permendikbud RI number 146 of 2014 on Curriculum 2013. Jakarta: Ministry of Education and Culture of the Republic of Indonesia Kharisma, Rizqi et al (2015). Perancantan Flash Multimedia Based Learning Media. DASI Journal. Vol. 16. 42-47.

Handayani, S., et al. (2020). The Effectiveness of Early Childhood Inclusive Education Textbook for Students of Inclusive Education Classes in UNIMED. Budapest International Research and Critics in Linguistics and Education (BirLE) Journal Vol 3 (1): 71-79.

Kurniawan, M.R., et al. (2020). The Ability of Gymnastics Motoric Perceptual Based on Local Culture for Early Childhood in Aceh Province. Budapest International Research and Critics in Linguistics and Education (BirLE) Journal Vol 3 (2): 749762.

Nanda, Erika (2012). Improving Children's Reading Ability through the word "Maze" Game in Padang Kindergarten: Pesona PAUD Journal, Vol 1 No.1 Pertiwi, Adhrina. (2016). Descriptive study of the process of reading early childhood. Journal of Children's Education. V (5). Edition 1.

Pramono, Budi, Joko, Aji. (2018). Developing interactive Multimedia in Learning Animals Among Early Childhood. JPAUD.V (1)

Putra, Lovandri Dawanda. (2015). Development of Interactive Learning Multimedia Recognizing numbers and letters for early childhood. Journallnnovation of Educational Technology V (2).

Simatupang, D., Sembiring, and S.W.S. (2019). The Effect of Numbered Heads Together Learning Model Towards Social Emotional Ability of Children 5-6 Years Old in Assisi Kindergarten Medan. Budapest International Research and Critics in Linguistics and Education (BirLE) Journal Vol 2 (4): 533-538. 